\begin{tabular}{lll}
\hline NOMOR XXI (1) & April 2015 & Halaman 14-22 \\
\hline
\end{tabular}

\title{
PENGARUH NILAI-NILAI BUDAYA GENERASI MILLENNIAL DAN BUDAYA SEKOLAH TERHADAP KETAHANAN INDIVIDU (Studi Di SMA Negeri 39, Cijantung, Jakarta)
}

\author{
Heru Dwi Wahana \\ Markas Besar Angkatan Darat \\ Email:wahanadipayana@gmail.com
}

\begin{abstract}
This research aimed to knew characteristic of Generasi Millennial's cultural values, cultural values influence Generasi Millennial and school culture to individual resilience in Country HIGHSCHOOL 39 Cijantungs Jakarta. Beside it was also to knew cultural correlation and values variable contribution Generasi Millennial and school culture variable to individual resilience.

The result of research showed cultural values Generasi Millennial at high category, school culture at high category, and so do individual resilience at high category. Research also found that cultural values Generasi Millennial and school culture joinly (simultan) had strong correlation, positive and significan to individual resilience. And so do, cultural values of Generasi Millennial and school culture had significan influence to individual resilience, either independent and also along with (simultan).
\end{abstract}

Keywords: Cultural Values of Generation of Millennial, School Culture, Individual Resilience.

\begin{abstract}
ABSTRAK
Penelitian ini bertujuan mengetahui karakteristik nilai-nilai budaya Generasi Millennial, pengaruh nilai-nilai budaya Generasi Millennial dan budaya sekolah terhadap ketahanan individu di SMA Negeri 39 Cijantung Jakarta. Disamping itu juga untuk mengetahui korelasi dan sumbangan variabel nilai-nilai budaya Generasi Millennial dan variabel budaya sekolah terhadap ketahanan individu.

Hasil penelitian menunjukkan nilai-nilai budaya Generasi Millennial berada pada kategori tinggi, budaya sekolah pada kategori tinggi, demikian juga ketahanan individu pada kategori tinggi. Penelitian juga menemukan bahwa nilai-nilai budaya Generasi Millennial dan budaya sekolah secara bersama-sama (simultan) memiliki korelasi yang kuat, positif dan significan terhadap ketahanan individu. Demikian juga, Nilai-nilai budaya Generasi Millennial dan budaya sekolah memiliki pengaruh yang significan terhadap ketahanan individu, baik berdiri sendiri maupun bersama-sama (simultan).
\end{abstract}

Kata Kunci: Nilai-Nilai Budaya Generasi Millennial, Budaya Sekolah, Ketahanan Individu.

\section{PENGANTAR}

Fenomena menarik dalam kehidupan masyarakat dewasa ini, maraknya budaya global (global culture) dan gaya hidup (life style) pop culture. Fenomena ini terjadi sebagai dampak dari arus globalisasi yang sudah tidak bisa dibendung lagi. Globalisasi yang sering dimaknai sebagai proses mendunianya sistem sosial-ekonomi-politik dan budaya sehingga dunia seperti menjadi tanpa tapal batas (the 
borderless world) yang sering dipahami pula sebagai suatu bentuk penyeragaman, dominasi, dan bahkan hegemoni negara-negara maju (Barat) terhadap negara-negara terbelakang atau bangsa yang sedang berkembang.

Salah satu fenomena penting proses globalisasi telah melahirkan generasi gadget, istilah yang digunakan untuk menandai munculnya generasi millennial. Gadget sebenarnya lebih pas diartikan dengan peralatan, sehingga generasi gadget dimaksudkan dengan generasi yang dalam kehidupannya selalu bersinggungan dengan yang namanya peralatan yang mengandung unsur teknologi informasi. Jadi seolah-olah berbagai peralatan tersebut telah menjadi bagian yang tak terpisahkan dari kehidupan mereka. Seolaholah berbagai alat high-technology telah menjadi bagian penting dalam kehidupannya (Zuhal, 2000; Naisbitt, 2002)

Menurut suvey di Amerika Serikat membuktikan jika berselancar di dunia maya, bermain game online, dan bermain situs jejaring sosial justru baik bagi perkembangan remaja. Digital Youth Project yang disponsori MacArthur Foundation selama tiga tahun berhasil membuktikan internet baik bagi perkembangan remaja. Proyek yang dilakukan selama tiga tahun itu melibatkan 800 remaja dan orang tua untuk mengetahui peningkatan kemampuan teknologi remaja. Hal ini juga mematahkan anggapan para orangtua yang menyatakan bermain internet hanya membuang waktu saja. Berdasarkan survei tersebut membuktikan walaupun penggunaan teknologi ini bukan untuk pendidikan tetapi bisa juga mendapatkan dampak positifnya (http://antioksidian. blogspot.com/2012/04/pengaruh-teknologiinformasi-dalam.html).
Menurut Severin dan Tankard (2005), sejumlah penelitian tentang dampak dan pemanfaatan internet menunjukkan bahwa internet menjadi sumber utama untuk belajar tentang apa yang sedang terjadi di dunia seperti untuk hiburan, bergembira, relaksasi, untuk melupakan masalah, menghilangkan kesepian, untuk mengisi waktu sebagai kebiasaan dan melakukan sesuatu dengan teman atau keluarga. Banyak manfaat yang dapat diperoleh dari internet, terutama dalam proses komunikasi dan penggalian informasi bagi seluruh masyarakat pengguna internet termasuk remaja. Di sana dapat dengan cepat mendapatkan informasi, bisa mencarinya dengan menggunakan google atau dengan cara yang lain, tetapi kebanyakan remaja menggunakan internet untuk mencari teman, chatting, kirim email dan mencari tugas-tugas kuliah atau tugas sekolah. Dikalangan remaja masa kini yang lagi marak-maraknya adalah friendster, Facebook dan Twitter. Mereka mencari teman melalui friendster maupun facebook dan bisa juga kirim-kirim foto atau dan lain sebagainya.

Di kalangan remaja Indonesia khususnya dari tingkat SMP dan SMA, internet sudah bukan hal yang asing lagi. Berdasarkan hasil survey yang diadakan oleh Spire Research \& Consulting bekerja sama dengan Majalah Marketing (2008) (http://marketing. co.id) mengenai trend dan kesukaan remaja Indonesia terhadap berbagai jenis kategori media, menunjukkan bahwa para remaja sudah mengerti dan menggunakan internet dalam kegiatan sehari-hari. Namun, para remaja sebagai salah satu pengguna internet belum mampu memilah aktivitas internet yang bermanfaat, dan cenderung mudah terpengaruh oleh lingkungan sosial tanpa 
mempertimbangkan terlebih dahulu efek positif atau negatif yang akan diterima saat melakukan aktivitas internet tertentu. Saat ini nampaknya telah terjadi kecenderungan pengguna internet yang sering mengenyampingkan nilai-nilai moral dan etika. Padahal dalam tatanan sosial, etika sangat diperlukan guna menghindari terjadinya pergesekan yang berujung kepada konflik.

Daradjat, (1982)semakin merosotnya moral para pelajar merupakan salah satu akibat dari pesatnya perkembangan teknologi yang tidak diimbangi dengan peningkatan kualitas budi pekerti pelajar, padahal perkembangan teknologi memang sangat dibutuhkan bangsa ini untuk dapat terus bersaing di era globalisasi. Kemerosotan moral banyak dipengaruhi oleh kondisi sosial-budaya dalam masyarakat sekitarnya. Lingkungan sosial yang buruk adalah bentuk dari kurangnya pranata sosial dalam mengendalikan perubahan sosial yang negatif

Dewasa ini keluarga Indonesia menghadapi tantangan seiring masuknya nilai-nilai baru atau nilai budaya global yang seringkali bertentangan dengan nilai budaya bangsa Dalam kondisi ini maka ketahanan dan bahkan kelangsungan hidup budaya nasional sangat tergantung dari ketahanan keluarga sebagai unit terkecil dari suatu bangsa dalam menghadapi arus penetrasi budaya global tersebut. Setiap individu atau pribadi dalam suatu keluarga Indonesia saat ini sedang menghadapi konflik antara Das Sein (apa yang senyatanya terjadi atau realita) dan Das Sollen (apa yang seharusnya terjadi atau yang diharapkan) dalam memahami nilai budaya nasional yang akan berakibat pada melemahnya ketahanan individu sebagai benteng dalam menghadapi nilai budaya global. (Soedarsono, 1999; Djahiri, 2006)
Di era global seperti saat ini, seseorang memerlukan pengendali yang kuat agar ia mampu memilih dan memilah nilai-nilai yang banyak sekali ditawarkan kepadanya. Oleh karena itu, agar seseorang tahan banting, maka bisa dilakukan dengan pendidikan, sebab jalan terbaik dalam membangun seseorang ialah pendidikan. Jalan terbaik dalam membangun masyarakat ialah pendidikan. Jalan terbaik dalam membangun negara ialah pendidikan. Jalan terbaik membangun dunia juga pendidikan. Secara sederhana, fokus pendidikan hanya tiga, yaitu membangun pengetahuan, membangun keterampilan (skill), dan membangun karakater. Berdasarkan ketiga elemen pendidikan tersebut, intinya hanya satu yakni basis utamanya adalah karakter dan karakter adalah buah dari kebudayaan.

Hasil survey, fakta-fakta dan uraian dari peneliti di atas, menunjukkan hadirnya nilainilai budaya generasi millenial (generasi yang menjadikan teknologi informasi sebagai gaya hidup atau lifestyle) sebagai fenomena baru yang dipicu oleh perkembangan teknologi informasi tentu akan berpengaruh terhadap aspek pendidikan sekolah maupun kehidupan individu dalam keluarga, baik positif maupun negatif. Masalah yang dapat dikemukakan, bagaimana karakteristik nilai-nilai budaya generasi millenial sebagai fenomena sosial?, karakteristik nilai-nilai budaya generasi millenial apa saja yang dapat mempengaruhi ketahanan individu?, seberapa jauh interaksi dan pengaruhnya faktor karakteristik nilai-nilai budaya generasi millenial dan budaya sekolah terhadap ketahanan individu? pertanyaanpertanyaan tersebut menjadi menarik untuk dijadikan kajian atau penelitian.

Lebih lanjut, dalam penelitian ini diajukan hipotesis sebagai berikut: Pertama, 
adanya korelasi dan pengaruh yang signifikan antara nilai-nilai budaya generasi millennial terhadap ketahanan individu. Kedua, adanya korelasi dan pengaruh yang significan antara budaya sekolah terhadap ketahanan individu. Ketiga, adanya korelasi dan pengaruh yang signifikan antara nilai-nilai budaya generasi millennial dan budaya sekolah terhadap ketahanan individu.

Penelitian ini menggunakan metode penelitian gabungan (mixed methods) antara metode penelitian kualitatif dan kuantitatif. Populasi penelitian ini adalah seluruh siswa kelas II (kelas sebelas) SMA 39 Cijantung Jakarta Timur. Dalam penelitian ini sampling yang digunakan adalah sistimatis random sampling dan untuk menarik populasi sampel yaitu siswa kelas II (kelas sebelas) SMA 39 Cijantung Jakarta Timur tahun ajaran 2013/2014 dan yang memiliki kelahir antara tahun 1982 sampai dengan 2001. Berdasarkan populasi siswa yang ada yaitu 360 orang dihasilkan sampel sebesar 186 orang untuk mejawab kuesioner secara terbuka dan tertutup serta sampel beberapa orang untuk interview mendalam yang meliputi: 10 orang siswa, Kepala Sekolah/Manajemen Sekolah, Guru Bimbingan Konsultasi, Guru PKN (Pendidikan Kewarganegaraan), Guru Agama, Guru TIK (Teknologi Informasi dan Komunikasi), 2 orang wali siswa (orang tua).

Data primer dan data sekunder yang diperoleh, dianalisa dengan statistik deskriptif dan statistik inferensia. Untuk menggambarkan karakteristik nilai-nilai budaya generasi millennial, budaya sekolah dan ketahanan individu digunakan statistik deskriptif yaitu dengan tabulasi. Untuk mengetahui hubungan antara variabel bebas yaitu nilai-nilai budaya generasi millennial dan budaya sekolah dengan variabel tak bebas yaitu ketahanan individu menggunakan statistik inferensia dengan teknik korelasi. Sementara itu, untuk mengukur tingkat pengaruh antara variabel bebas yaitu nilai-nilai budaya generasi millennial dan budaya sekolah dengan variabel tak bebas yaitu ketahanan individu menggunakan statistik inferensia dengan teknik regresi ganda. Sebelum dilakukan korelasi dan regresi ganda dilakukan uji asumsi klasik meliputi: uji normalitas, uji multikolinieritas, uji heterokedastisitas dan uji autokorelasi.

\section{PEMBAHASAN}

\section{Kondisi Nilai-Nilai Budaya Generasi Millennial, Kondisi Budaya Sekolah Dan Kondisi Ketahanan Individu.}

Hasil analisis data menunjukan kondisi nilai-nilai budaya generasi millennial dalam penelitian berada pada kategori tinggi, kondisi budaya sekolah menunjukkan kategori tinggi demikian juga variabel ketahanan individu berada dalam kategori tinggi. Berdasarkan ketiga kelas atau kategori yang telah ditentukan, maka nilai-nilai budaya generasi millennial menunjukkan semua indikator dalam kategori tinggi dengan total nilai sebesar 14956 yang terdiri dari: hakikat hidup dengan nilai sebesar 1979, hakikat kerja/karya sebesar 3770 , hubungan manusia dengan ruang dan waktu sebesar 3011, hubungan manusia dengan alam sebesar 2619 dan hubungan manusia dengan sesama manusia sebesar 3577.

Berdasarkan ketiga kelas atau kategori yang telah ditentukan, budaya sekolah menunjukkan semua indikator dalam kategori tinggi. Melihat kondisi semua indikator budaya sekolah tersebut, maka dapat diinteprestasikan bahwa kondisi 
budaya sekolah SMA 39 Cijantung Jakarta dalam kondisi sangat baik dengan total nilai skor sebesar 15205 yang terdiri dari: aspek kultur sosial sebesar 3028, aspek kultur akademik sebesar 2828, aspek kultur mutu sebesar 5188 dan aspek artifak sebesar 4161.

Untuk variabel katahanan individu berdasarkan ketiga kelas atau kategori yang telah ditentukan, juga menunjukkan semua indikator dalam kategori tinggi. Hal ini dapat interprestasikan bahwa ketahanan individu siswa SMA 39 Cijantung Jakarta secara umum dalam kondisi sangat baik dengan total nilai skor sebesar 14255 yang terdiri dari: ketahanan fisik sebesar 3957, ketahanan mental/psikologis sebesar 5129 dan ketahanan sosial sebesar 5175 .

\section{Karakteristik Nilai-Nilai Budaya Generasi Millennial SMA 39 Cijantung}

Karakteristik dan ciri khas nilai-nilai budaya generasi millennial yang ditunjukkan siswa SMA 39 Cijantung antara lain adalah menjadikan teknologi sebagai gaya hidup (lifestyle), sebagai generasi yang ternaungi (sheltered), karena mereka lahir dari orang tua yang terdidik. Mereka multi talented, multi language, lebih ekspresif dan eksploratif. Pandangan terhadap hakekat hidup, selalu yakin, optimistik, percaya diri, menginginkan kesimplean, dan segala sesuatunya serba instan. Pandangan terhadap hakekat karya atau kerja, memandang prestasi merupakan sesuatu yang harus dicapai, bekerja dan belajar lebih interaktif melalui kerjasama tim, kolaborasi dan kelompok berpikir, mandiri dan tersturuktur dalam penggunaan teknologi, communication gadget, dalam akses internet lebih menyukai petunjuk visual atau gambar.
Dalam melihat hubungan manusia dengan ruang dan waktu, ciri generasi millennial dalam berkomunikasi bersifat Instant Communication di lingkungan real time, Network Development, yaitu mengembangkan jaringan yang memungkinkan generasi ini untuk terhubung satu sama lain untuk berkoneksi dan kolaborasi. Terkait dengan prinsip dasar hubungan manusia dengan alam, mempunyai prinsip pemanfaatan dan sekaligus pelestarian lingkungan alam. Manusia harus menguasai teknologi dan ilmu pengetahuan untuk digunakan dalam pemanfaatan, pengelolaan, kelestarian sekaligus bagi keselarasan, harmoni dan penguasaan alam demi kemanfaatan umat manusia dan alam sekitarnya. Sementara itu, dalam melihat hubungan manusia dengan sesama manusia, lebih terbuka terhadap berbagai akses informasi yang bersifat lintas batas, cenderung lebih permisif terhadap keanekaragaman. Mereka tidak peduli tentang privasi dan bersedia untuk berbagi rincian intim tentang diri mereka sendiri dengan orang asing. Budaya membuat status merupakan aktivitas sehari-hari. Cyberculture adalah sebuah kebudayaan baru di mana seluruh aktivitas kebudayaannya dilakukan dalam dunia maya yang tanpa batas. Namun demikian generasi millennial tetap berpandangan bahwa keluarga merupakan pilar yang sangat penting bagi kehidupannya.

\section{Korelasi Nilai-Nilai Budaya Generasi Millennial Dan Budaya Sekolah Terhadap Ketahanan Individu}

Berdasarkan uji statistik atau uji korelasi, menunjukkan dari data-data keseluruhan tampak bahwa korelasi antara nilai-nilai budaya generasi millennial dengan ketahanan individu dalam 
kategori sedang. Hubungan itu cukup erat dan positif artinya naiknya intensitas nilai-nilai budaya generasi millennial maka akan memiliki korelasi kenaikan dengan intensitas yang cukup atau sedang terhadap ketahanan individu. Budaya sekolah juga terbukti memiliki hubungan yang kuat dan positif terhadap ketahanan individu, artinya semakin tinggi budaya sekolah maka semakin tinggi pula ketahanan individu. Apabila dibandingkan antara nilai-nilai budaya generasi millennial dan budaya sekolah maka dapat diketahui bahwa budaya sekolah memiliki hubungan atau korelasi yang lebih kuat terhadap ketahanan individu. Nilai $r$ untuk korelasi nilai-nilai budaya generasi millennial terhadap ketahanan individu adalah 0,450 dengan nilai sumbangan sebesar 20,29\% sedangkan nilai r untuk korelasi budaya sekolah terhadap ketahanan individu adalah 0,622 dengan nilai sumbangan sebesar 38,74\%.

Berdasarkan data-data tersebut juga dapat diinterpretasikan bahwa nilai-nilai budaya generasi millennial dan budaya sekolah pada akhirnya secara bersamasama memiliki korelasi yang kuat terhadap tingginya ketahanan individu khususnya bagi siswa SMA 39 Cijantung. Hal ini terlihat nyata dari korelasi ganda nilai-nilai generasi millennial dan budaya sekolah terhadap ketahanan individu sebesar 0,650 dan sumbangannya secara bersama-sama yaitu sebesar 42,25 \%. Dengan demikian masih ada faktor lain yang memberikan sumbangan terhadap ketahanan individu sebesar 57,75\% dari variabel lainnya yang tidak masuk dalam penelitian ini.

Berturut-turut variabel nilai-nilai budaya generasi millennial dari sumbangannya yang terbesar ke yang terkecil terhadap ketahanan individu adalah indikator hubungan manusia dengan sesama manusia sebesar $17,10 \%$, nilainilai hakikat hidup sebesar $12,58 \%$, nilai-nilai hakikat kerja/karya sebesar $11,90 \%$, hubungan manusia dengan ruang dan waktu sebesar $8,83 \%$ dan yang terkecil adalah hubungan manusia dengan alam sebesar 5,59\%. Variabel budaya sekolah yang sumbangannya lebih besar dari nilai-nilai budaya generasi millennial terhadap ketahanan individu berturut-turut adalah indikator budaya mutu dengan nilai $r$ sebesar 0,508 dengan nilai sumbangan sebesar $25,82 \%$, diikuti indikator aspek artifak dengan nilai $r$ sebesar 0,491 dengan nilai sumbangan sebesar 24,10\%, disusul indikator aspek budaya akaemik dengan nilai $r$ sebesar 0,466 dengan nilai sumbangan sebesar $21,69 \%$, sedangkan aspek kultur sosial merupakan indikator yang paling kecil dengan nilai r sebesar 0,414 dengan nilai sumbangan sebesar $17,16 \%$.

Sementara itu berturut-turut variabel nilai-nilai budaya generasi millennial dari sumbangannya terhadap masing-masing indikator ketahanan individu mulai dari yang terkecil adalah variabel nilai-nilai budaya generasi millennial terhadap ketahanan mental/ psikologis sebesar $11,11 \%$, variabel Nilai-nilai budaya generasi millennial terhadap ketahanan fisik sebesar $12,10 \%$, dan terbesar variabel Nilai-nilai budaya generasi millennial terhadap ketahanan sosial sebesar 16,09\%. Untuk variabel budaya sekolah mulai sumbangan yang terkecil berturut adalah budaya sekolah terhadap ketahanan fisik dengan nilai $r$ sebesar 0,472 dengan nilai sumbangan sebesar $22,27 \%$, budaya sekolah terhadap ketahanan mental/psikologis dengan nilai $r$ sebesar 0,510 dengan nilai sumbangan sebesar $25,98 \%$ dan terbesar budaya sekolah terhadap ketahanan sosial dengan nilai $r$ sebesar 0,514 dengan nilai sumbangan sebesar $26,42 \%$. 


\section{Pengaruh Nilai-Nilai Budaya Generasi Millennial Dan Budaya Sekolah Terhadap Ketahanan Individu.}

Untuk menjelaskan nilai pengaruh antar variabel menggunakan analisis regresi. Analisis regresi untuk menggambarkan garis yang menunjukan arah hubungan antar variabel, serta dipergunakan untuk melakukan prediksi. Analisis ini dipergunakan untuk menelaah hubungan antara dua variabel atau lebih, terutama untuk menelusuri pola hubungan yang modelnya belum diketahui dengan sempurna. Untuk melihat pengaruh nilai-nilai budaya generasi millennial dan budaya sekolah terhadap ketahanan individu secara bersama-sama (simultan) menggunakan uji F. Uji F digunakan untuk mengetahui apakah variabel-variabel independen secara simultan berpengaruh signifikan terhadap variabel dependen. Sementara itu, Untuk mencari pengaruh variabel bebas secara individual atau parsial digunakan uji t-test. Uji t-test ini digunakan untuk mengetahui apakah variabel-variabel independen secara parsial berpengaruh nyata atau tidak terhadap variabel dependen.

Berdasarkan uji t-test menunjukkan nilai sig 0,001 . Nilai sig lebih kecil dari nilai probabilitas 0,05 , atau nilai $0,001<0,05$ dan nilai t hitung untuk variabel nilai-nilai budaya generasi millennial adalah sebesar 3,350. Nilai tersebut di atas nilai $\mathrm{t}$ tabel untuk $\mathrm{N}=186$ atau $\mathrm{df}=183$ yaitu sebesar 1,65322 sehingga diinterpretasikan bahwa variabel nilai-nilai budaya generasi millennial mempunyai pengaruh yang signifikan terhadap Ketahanan Individu. Untuk variabel budaya sekolah menunjukkan nilai sig 0,000. Nilai sig lebih kecil dari nilai probabilitas 0,05 , atau nilai $0,000<0,05$ dan nilai thitung untuk variabel nilai-nilai budaya sekolah adalah sebesar 8,349 . Nilai tersebut di atas nilai t tabel untuk $\mathrm{N}=186$ atau $\mathrm{df}=183$ yaitu sebesar 1,65322 sehingga diinterpretasikan bahwa variabel budaya sekolah mempunyai pengaruh yang signifikan terhadap ketahanan individu.

Berdasarkan uji $\mathrm{F}$, pengujian secara simultan X1 dan X2 terhadap Y: berdasarkan tabel ANOVA terdapat nilai sig 0,000 dan Nilai F-hitungnya 67,030. Dengan tingkat signifikansinya $5 \%$, df1 $=2$ dan df2 $=183$ didapat nilai F-tabel sebesar 3,05. Karena nilai signifikansinya 0,000 lebih kecil dari nilai probabilitas 0,05 , atau nilai $0,000<0,05$, dan nilai F-hitung $(67,030)>$ F-tabel $(3,05)$, maka terdapat pengaruh yang signifikan secara bersama-sama (simultan) nilai-nilai budaya generasi millennial dan budaya sekolah terhadap ketahanan individu.

\section{SIMPULAN}

Berdasarkan uraian dan penjelasan tersebut di atas, maka dapat ditarik kesimpulan sebagai berikut:

Pertama, karakteristik nilai-nilai budaya generasi millennial yang ditunjukkan siswa SMA 39 Cijantung antara lain: Menjadikan teknologi sebagai lifestyle, generasi yang ternaungi (sheltered), lahir dari orang tua yang terdidik, multi talented, multi language, ekspresif dan eksploratif, selalu yakin, optimistik, percaya diri, menginginkan kesimplean, dan segala sesuatunya serba instan, prestasi merupakan sesuatu yang harus dicapai, bekerja dan belajar lebih interaktif melalui kerjasama tim, kolaborasi dan kelompok berpikir, mandiri dan tersturuktur dalam penggunaan teknologi, communication gadget, dalam akses internet lebih menyukai petunjuk visual/gambar, 
generasi millennial dalam berkomunikasi bersifat Instant Communication, real time, Network Development, lebih terbuka terhadap berbagai akses informasi yang bersifat lintas batas, cenderung lebih permisif terhadap keanekaragaman, tidak peduli tentang privasi dan bersedia untuk berbagi rincian intim tentang diri mereka sendiri dengan orang asing,budaya membuat status merupakan aktivitas seharihari, cyberculture adalah sebuah kebudayaan baru di mana seluruh aktivitas kebudayaannya dilakukan dalam dunia maya yang tanpa batas,generasi millennial tetap berpandangan bahwa keluarga merupakan pilar yang sangat penting bagi kehidupannya.

Kedua, hasil analisis data menunjukan kondisi nilai-nilai budaya generasi millennial dalam penelitian berada pada kategori tinggi, kondisi budaya sekolah menunjukkan kategori tinggi demikian juga variabel ketahanan individu berada dalam kategori tinggi.

Ketiga, hasil uji korelasi menunjukkan nilai-nilai budaya generasi millennial terhadap ketahanan individu memperoleh nilai korelasi sebesar $r=0,45$ artinya nilai-nilai budaya generasi millennial memiliki korelasi sedang dan positif terhadap ketahanan individu, dengan kontribusi atau sumbangan nilai-nilai budaya generasi millennial sebesar $\mathrm{R}^{2}=20,29 \%$ terhadap ketahanan individu. Untuk variabel budaya sekolah terhadap ketahanan individu memperoleh nilai korelasi $r=0,622$ yang berarti bahwa hubungan atau korelasi dalam kategori kuat dan positifantara budaya sekolah dan ketahanan individu, dengan kontribusi atau sumbangan budaya sekolah sebesar $\mathrm{R}^{2}=38,74 \%$ terhadap ketahanan Individu. Hasil uji korelasi ganda menunjukkan nilainilai budaya generasi millennial dan budaya sekolah secara bersama-sama (simultan) terhadap ketahanan individu memperoleh nilai korelasi sebesar $r=0,650$ yang berarti bahwa hubungan atau korelasi dalam kategori kuat atau erat antara nilai-nilai budaya generasi millennial dan budaya sekolah secara bersamasama (simultan) terhadap ketahanan individu, dengan kontribusi atau sumbangan nilainilai budaya generasi millennial dan budaya sekolah sebesar $\mathrm{R}^{2}=42,25 \%$. Sementara itu $57,25 \%$ sisanya merupakan kontribusi dari faktor-faktor lain selain faktor yang diwakili oleh variabel bebas pada penelitian ini.

Keempat, berdasarkan analisis data dan uji t-test secara parsial menunjukkan bahwa variabel nilai-nilai budaya generasi millennial mempunyai pengaruh yang signifikan terhadap ketahanan individu, demikian juga budaya budaya sekolah mempunyai pengaruh yang signifikan terhadap ketahanan individu. Berdasarkan pengujian secara simultan nilainilai budaya generasi millennial (X1) dan budaya sekolah (X2) terhadap ketahanan individu (Y) menunjukkan secara bersamasama (simultan) nilai-nilai budaya generasi millennial dan budaya sekolah berpengaruh signifikan terhadap terhadap ketahanan individu.

\section{DAFTAR PUSTAKA}

Daradjat, Zakiyah. (1982). Pendidikan Agama Dalam Pendidikan Mental, Cet. ke-4. Jakarta: Cv. Bulan Bintang.

Djahiri, A.K. (2006). “Esensi Pendidikan Nilai Moral dan Pendidikan kewarganegaraan di Era Globalisasi," Pendidikan Nilai Moral dalam Dimensi Pendidikan Kewarganegaraan, Bandung: Laboratorium Pkn FPIPS UPI.

Naisbitt, John. Et. All. 2002. High Tech High Touch. Jakarta: Pustaka Mizan. 
Severin, W. J and Tankard, J.W. (2005). Communication Theoris, methods \& Uses in The Massa

Soedarsono, Soemarno. (2009). Karakter Mengantar Bangsa Dari Gelap Menuju Terang. Jakarta: PT Elex Media Komputindo,

Zuhal. 2000. Visi Iptek Memasuki Milenium III. Jakarta: Penerbit Universitas Indonesia (UI-Press).

\section{Internet:}

(http://antioksidian.blogspot.com/2012/04/ pengaruh-teknologi-informasi-dalam. html)

(http: // marketing.co.id) 